\title{
Bats of the California Channel Islands: new records with new methods
}

\author{
Patricia E. Brown ${ }^{1, *}$ and William E. Rainey ${ }^{2}$ \\ ${ }^{1} 134$ Eagle Vista, Bishop, CA 93514 \\ 22556 Hilgard Ave., Berkeley, CA 94709-1105
}

\begin{abstract}
Eight bat species were known and documented from the California Channel Islands when J.C. Von Bloeker (1967) presented at the First California Islands Symposium in 1965. Additional bat surveys by P.E. Brown (1980) in the 1970s resulted in "Distribution of bats of the California Channel Islands," which was presented at the second symposium in 1978. Methods of detecting and identifying bats have changed over the past century. Museum collection methods using shotguns have been replaced by mist-netting and recording of echolocation calls. Currently, capture or acoustic records have identified 14 bat species (56\% of the 25 species known to occur in California) on 6 of the 8 California Channel Islands, with occasional sightings of flying bats on Anacapa and San Miguel Islands. Bats now compose $78 \%$ of the native mammals on the islands (Collins 2012). Acoustic recording equipment has become smaller and easier to use in the field, and recorded echolocation signals are now recognized as valid "vouchers" if the species emits calls that are separable from others. For example, echolocation signals have identified western red bat (Lasiurus blossevillii), hoary bat (Lasiurus cinereus), western yellow bat (Lasiurus xanthinus), and Mexican free-tailed bat (Tadarida brasiliensis) from San Nicolas Island, and western mastiff bat (Eumops perotis) and canyon bat (Parastrellus hesperus) from Santa Cruz Island. Acoustic data have identified 3 new species for the California Channel Islands, as well as several new records on individual islands. As acoustic monitoring and other techniques are used more extensively, the number of species documented will increase and the proportions that are resident, vagrant, or transient on each island can be better resolved.
\end{abstract}

Resumen.-Ocho especies de murciélagos fueron documentadas al momento en que J.C. Von Bloeker (1967) expuso en el Primer Simposio de las Islas de California en 1965. Los estudios adicionales sobre murciélagos de P.E. Brown (1980) en la década de 1970, resultaron en "La distribución de los murciélagos en las Islas del Canal de California," en el Segundo Simposio de 1978. Los métodos para detectar e identificar murciélagos cambiaron durante el siglo pasado. Las capturas para las colecciones de museos utilizando escopetas se reemplazaron por trampeos con redes de niebla y grabación de llamadas de ecolocalización. Actualmente, los registros de captura o acústicos han identificado catorce especies de murciélagos (el 56\% de las 25 especies se encuentran en California) en seis de las ocho Islas del Canal de California, con avistamientos ocasionales de murciélagos voladores en las islas Anacapa y San Miguel. Los murciélagos constituyen ahora el 78\% de los mamíferos nativos de las islas (Collins 2012). El equipo de grabación acústica ahora es más pequeño y fácil de usar en el campo, y las señales de ecolocalización registradas se reconocen como "comprobantes" válidos, cuando una especie emite llamadas independientes unas de otras. Por ejemplo, las señales de ecolocalización han identificado al murciélago rojo del desierto (Lasiurus blossevillii), al murciélago ceniciento (Lasiurus cinereus), al murciélago amarillo de la laguna (Lasiurus xanthinus) y al murciélago cola de ratón (Tadarida brasiliensis) en la isla San Nicolás, así como al murciélago gigante de bonete (Eumops perotis), y al pipistrelo del oeste americano (Parastrellus hesperus) en la Isla Santa Cruz. A través de los datos acústicos, se identificaron tres nuevas especies en las Islas de California, y varios registros nuevos en islas individuales. Dado que la monitorización acústica y otras técnicas se usan más extensamente, la cantidad de especies documentadas aumentará, logrando esclarecer el porcentaje de especies residentes, vagabundas o transitorias en cada isla.

\section{History of Methods for Bat Surveys}

Methods for the study of bats have changed over the past century since the first collection of a Yuma myotis (Myotis yumanensis) by Bancroft on Santa Catalina Island on 1 August 1893. Between 1893 and 1948, Von
Bloeker and others collected 7 more species of bats on the 5 largest islands (Table 1) either by shooting, by hand, or with insect nets in building roosts (Von Bloeker 1967). On shooting bats Louise Kellogg (1916) wrote, "There is nothing quite so wasteful of ammunition as

*Corresponding author: patbobbat@aol.com 


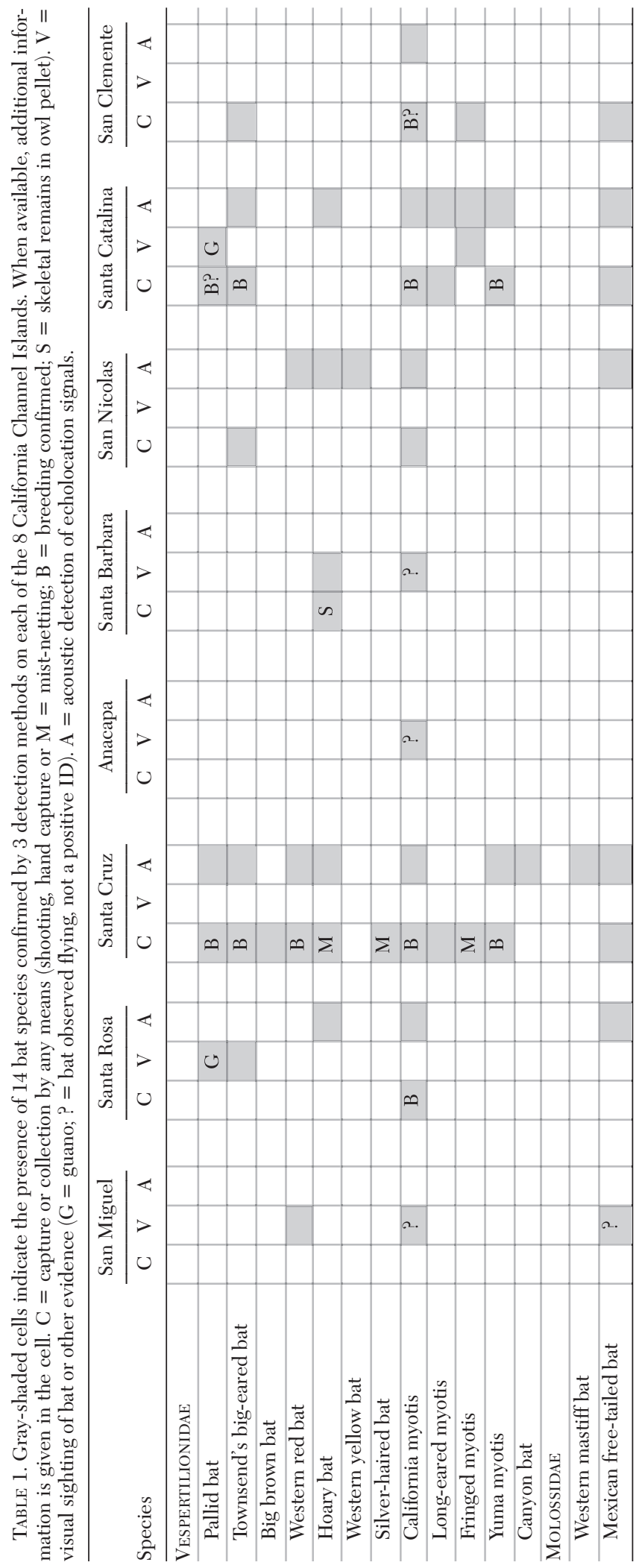


shooting at bats. At Kangaroo Creek and Castle Lake we used to spend the evenings until dark trying to hit the wavering, fluttering things." Fortunately, this capture method is no longer in vogue. The historic records (1893-1964) usually resulted in the removal of those individuals from the islands to be preserved in collections. Early collectors concentrated on the larger islands that had diverse habitat and sometimes facilities where they could stay, such that the most specimens are from buildings and near areas of human habitation. During 50 years of initial collecting effort (1893-1943), 8 bat species were described, constituting at the time $53 \%$ of the islands' native land mammals (Von Bloeker 1967, Brown 1980).

Mist nets for bat capture were not available to Von Bloeker during collecting in the 1940s on the Channel Islands. They were first employed for capturing bats by Dalquest (1954) in Mexico. While mist nets are associated with some bias in the species captured (Kunz and Kurta 1988), the method provides a means to capture bats that fly after dark and/or roost in settings other than buildings (trees, remote caves, and rock crevices). On Santa Cruz and Santa Catalina Islands mist-netting was first used for bats in the 1970s over water and other foraging habitats (Brown 1980, Brown et al. 1994). Netting over water added 3 species of tree-roosting bats to the Santa Cruz Island total: hoary bat (Lasiurus cinereus), western red bat (Lasiurus blossevillii), and silverhaired bat (Lasionycteris noctivagans).

There is a bias with each collecting method in the number and species of bats identified. Collection of flying bats with shotguns requires skill and selects bats that fly relatively low before total darkness, such as Myotis species. The capture of bats in roosts (caves, mines, and buildings) with hands or nets is usually easier, but can be very disruptive to maternity colonies. Even if bats are not present in a roost at the time of a survey, guano may used to identify some species. The size, shape, color, and deposition patterns of guano, as well as associated culled portions of prey (arthropod legs, wings, elytra, heads, etc.) are used in species identification (P.E. Brown personal observation; Ross 1961, Johnston and Fenton 2001). Mist nets can be used in calm weather to capture bat species that fly low and/or are attracted to relatively calm surface water. Net movement in any wind alerts the bats to the hazard. Since wind is a constant feature on most of the California Channel Islands, mist net captures have been most successful in the sheltered canyons of Santa Catalina and Santa Cruz Islands. Capture of bats by any of the above means provides not only positive species identification, but also information on sex, age, and reproductive condition.

Griffin $(1944,1958)$ coined the term "echolocation" to describe how bats emit ultrasonic signals and listen for returning echoes to locate prey and obstacles in darkness. This discovery was made possible after equipment to detect ultrasound was developed prior to World War II (Pierce and Griffin 1938). For decades following, the equipment to record signals was used only in laboratory conditions and was not a method available to Von Bloeker and the other historic-era Channel Islands collectors. Field recording of bat echolocation signals as a possible identification method for bats has become more feasible in the past 25 years with development of small battery-operated ultrasound detectors that can operate for several hours and transfer call samples to portable storage media (tape, disk, laptop hard drive, etc.). The technology continues to change, offering multiple smaller detector designs with selective detection and display modes, and storage of bat signals on removable digital media of increasing storage capacity. Supported by external batteries and solar panels, bat detectors in weatherproof enclosures can now be operated in remote locations for months (Figs. 1A, 1B). Bat activity can be monitored over several seasons or years, allowing the detection of seasonal and longer-term patterns (e.g., Broderick 2010) and potentially recording migratory and rare species that could be missed by short-term deployment of detectors. A long-term monitoring station on San Nicolas Island recorded western yellow bats (Lasiurus xanthinus) in 2015 , a species not captured on any of the Channel Islands or on the adjacent California mainland (Rainey and Brown 2017). Two similar detector stations installed on Santa Cruz Island in late July 2017 recorded canyon bats (Parastrellus hesperus) for the first time in the Channel Islands.

The method of recording echolocating bats can be used in many habitats and weather conditions and is a powerful tool for documenting 

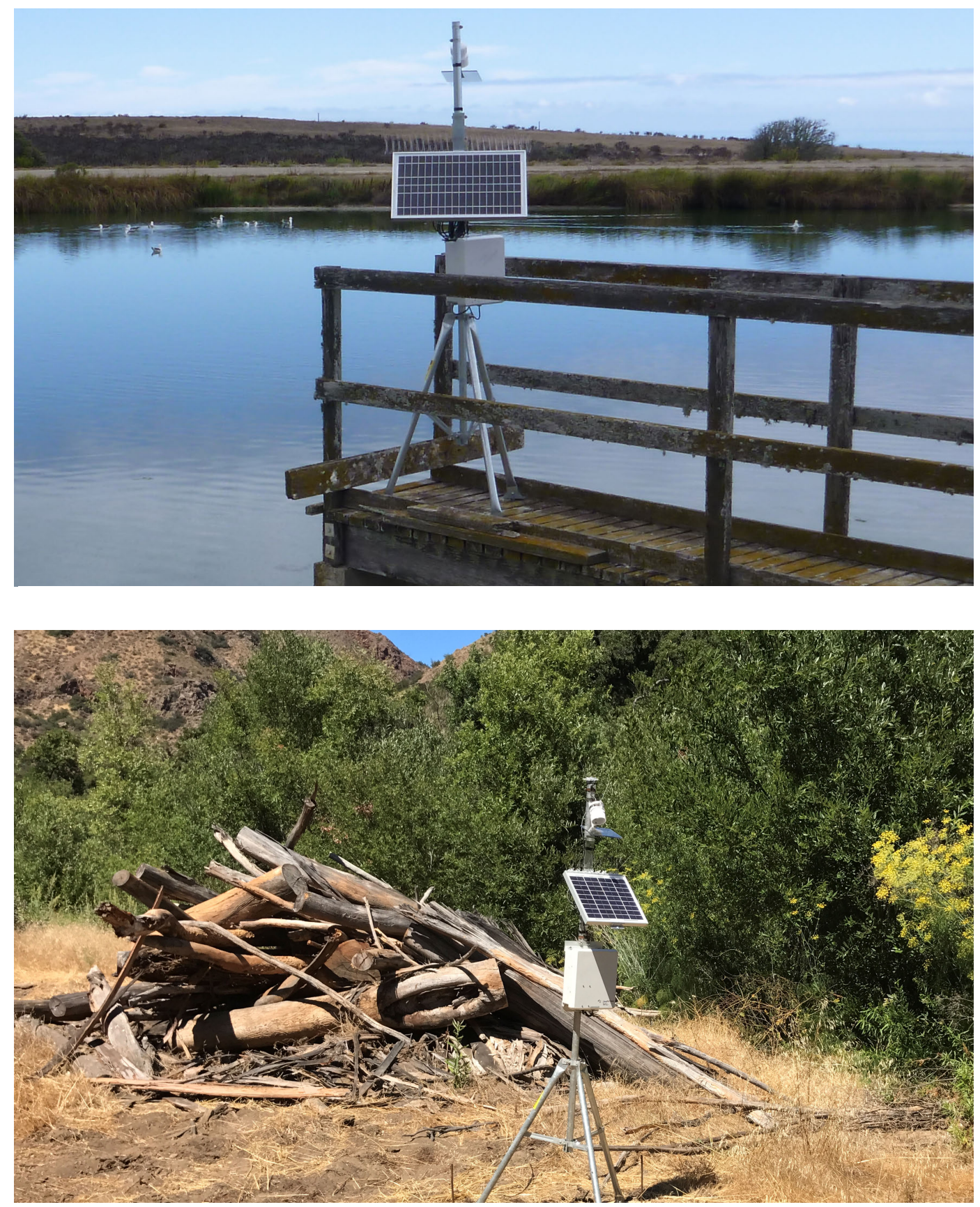

Fig. 1. Long-term solar passive bat detectors. Anabat SD2 (Titley Electronics, Columbia, MO) in enclosure with external microphone and reflector above: A, East sewage pond, San Nicolas Island $\left(33.25394^{\circ},-119.48038^{\circ}\right)$; B, Cañada del Puerto stream corridor, Santa Cruz Island $\left(33.99809^{\circ},-119.71530^{\circ}\right)$.

bats that are otherwise difficult to capture (O’Farrell and Gannon 1999). However, though useful for species identification, bat call analysis does not generally provide information on sex, age, or reproductive condition. The quantity of calls with a stationary detector does not usually equate to the number of bats but does furnish a relative index of bat activity. For 
example, acoustic bat activity around an outdoor light with insects is often continuous through a night and could represent one bat, while recordings made along a commuting route between the roost and the foraging area may represent many bats with only a single call sequence per individual. Moving by foot or vehicle along transects may provide the opportunity to count bats based on call recording and this method has been used by bat biologists on Santa Rosa and Santa Cruz Islands (C. Drost personal communication).

Several factors influence the recording of acoustic signals: the frequency, intensity, and directionality of the emitted call; the frequency sensitivity of the microphone; and the distance and orientation of the bat relative to the microphone. Calls of most bats that pursue flying insects in open air are remarkably loud, but bats employing other foraging strategies (e.g., foliage gleaning or listening for prey-produced sounds) may emit fainter signals and have a limited detection range (Jakobsen et al. 2013). For example, Mexican free-tailed bats (Tadarida brasiliensis) emit loud, relatively low-frequency calls that can be recorded from hundreds of feet away, whereas Townsend's big-eared bats (Corynorhinus townsendii) usually use faint signals that are seldom detected from over 10 feet away (P.E. Brown and W.E. Rainey personal observations; Corcoran and Conner 2017). Bat calls are typically directional (Hulgard et al. 2016), and bats flying away from a microphone are often not recorded (Rainey personal observation). Western mastiff bats (Eumops perotis) may not be recorded with many ultrasound detectors because the largely audible call frequency range is intentionally reduced by the high-pass "noise" filters usually active in these detectors. The calls of this species are audible to most people with good hearing, and the bats may be heard long before being recorded. The only record prior to 2017 for western mastiff bats on Santa Cruz Island was from audible signals heard by several people at night (Brown et al. 1994). At times, certain bat species will orient visually and emit no echolocation calls. Pallid bats (Antrozous pallidus) see very well in moonlight and may not always echolocate, although their distinctive acoustic communication signals may indicate their presence (Brown 1976).
Species identification from recorded calls is made by comparison with "voucher" calls or with software based on information extracted from sets of voucher calls obtained from known hand-released or otherwise identifiable bats (O'Farrell et al. 1999). Acquiring an adequate sample of the vocal repertoire of multiple species is a fundamental challenge for bat identification (Britzke et al. 2013). Different bat species can at times use very similar signals, and one species can employ a variety of calls based on the perceptual task and the surrounding habitat (Obrist 1995). A knowledge of which bat species are common to the area (as well as those that may be present but uncommon) is important in the acoustic identification process. Bat detector designs and software programs that facilitate call identification have proliferated and offer an array of options. Recent cautionary papers address the challenges of acoustic identification including inadequate understanding of species call repertoires, performance of automated identification software, and instrumentation issues (Lemen et al. 2015, Russo et al. 2017, Ratcliffe and Jakobsen 2018). This paper will not address this rapidly changing technology. Rather it describes the species accumulation of bats on the California Channel Islands using a variety of techniques: acoustic, capture, and roost surveys.

As with other land animals that have colonized the California Islands, bats need to first reach the island and then find suitable roosting and foraging habitat. To establish a breeding population, both males and females (or a pregnant bat) need to have made the crossing within a window of a few years. Only 5 species of bats have been identified as breeding on one or more of the islands by the capture of reproductive female or juvenile bats (California and Yuma myotis; Townsend's big-eared, red, and pallid bats). Bats can live 10-15 years on average (Barbour and Davis 1969), and therefore colonists may persist on the island for some time without a reproductive colony. Some species undertake long seasonal migrations (Cryan 2003) and may use the islands as stopovers, while others may be inadvertently carried by wind from the mainland. In this respect bats are analogous to birds, although bats are more difficult to detect due to their nocturnal and secretive nature. Bird-watchers are much 
more numerous, and require less equipment than bat biologists, so documentation of bat occurrences on the Channel Islands has progressed more slowly.

The early recognition of possible over-ocean mass migration by North American bats was based on seasonal aggregations on the New England coast and nearshore islands, and observations of the same species seasonally occurring on Bermuda at a much greater distance from the continent (Miller 1897, Van Gelder and Wingate 1961). More extensive research on bat migration in northern Europe reveals seasonal movements across the Baltic and parts of the North Sea by multiple species, including small vespertilionids (Rydell et al. 2014). Environmental studies associated with developing extensive offshore wind turbine installations (motivated in part by already substantial bat mortality at onshore facilities) has more surprisingly shown several species flying and foraging over the ocean at least 12 miles from the coast, outside of migration seasons (Ahlen et al. 2009, Poernick et al. 2013).

The following bat species accounts are organized according to the method by which the species' occurrence was first described from one or more of the California Channel Islands: capture (shooting, capture at the roost, or mist-netting) or acoustic (Table 1). Ultimately some of the bats were detected by multiple methods.

\section{CAPture Records \\ Yuma Myotis \\ (Myotis yumanensis)}

Throughout its range, the foraging habitat of Yuma myotis is usually near relatively calm open water, and the bats can be observed flying low over the water while feeding on emerging aquatic insects (Brigham et al. 1992). Prey are typically captured by trawling (i.e., raking the water surface with the claws of their large feet). The Yuma myotis is more closely associated with reservoirs than any other bat in California and is often found roosting on allied infrastructure such as bridges and dams (Rainey and Brown personal observations). Santa Catalina has large permanent ponds or reservoirs, in contrast to most of the Channel Islands. The first bat specimen collected on the Channel Islands was a male Yuma myotis from Avalon on Santa Catalina
Island on 1 August 1893. Subsequently, Brown (1980) found Yuma myotis forming large maternity colonies on Santa Catalina, primarily in the buildings and bridges of Middle Ranch Canyon. In late spring, pregnant females were found roosting under tarpaper at Camp Cactus, and a large night roost colony occupied the deserted army bunker above Ben Weston beach. Late in the evening, the barn at Middle Ranch is often alive with bats swooping and darting after insects (Brown 1980, Brown and Berry 2002; J. King personal communication). On Santa Catalina, most of the acoustic signals for this species recorded by Brown and Berry (2002) were near ponds and reservoirs.

The very similar echolocation call characteristics of Yuma and California myotis make many call sequences of these species indistinguishable. Typically, sequences recorded from both species are effectively in high-clutter settings and are composed of steep pulses that reach their lowest slope around $45-50 \mathrm{kHz}$. A relatively common practice is to label these calls as a $50-\mathrm{kHz}$ acoustic category that includes both species (O’Farrell et al. 1999). On Santa Cruz Island, all steep calls ending near $50 \mathrm{kHz}$ have been previously attributed to California myotis. However, on 28 July 2017 , a postlactating Yuma myotis was mist-netted by us over a small pool at a stream crossing in Cañada del Puerto, and the following night a male was captured over the stream about $100 \mathrm{~m}$ south of Prisoners Harbor. We also captured a male Yuma myotis roosting between the rafters of the horse barn at Stanton Ranch among numerous California myotis (which they superficially resemble when seen in a crevice). More Yuma myotis individuals may have been present, but most of the bats roosted beyond our reach. Although we mistnetted over the swimming pool at the Stanton Ranch (the only relatively large body of permanent freshwater on Santa Cruz Island), no Yuma myotis were captured or observed with night-vision equipment.

\section{California Myotis \\ (Myotis californicus)}

This small myotis is ubiquitous in most natural habitats in the southwestern United States below about $2134 \mathrm{~m}$ (7000 ft.) elevation (Barbour and Davis 1969, Simpson 1993). Whereas Yuma myotis are usually found near open freshwater, California myotis are often 
recorded in drier habitats where they forage in the open for small aerial insects, a resource readily available on at least some of the Channel Islands once the bats have made the ocean crossing. The capture of reproductive females indicates breeding on the 3 largest islands (Santa Cruz, Santa Rosa, and Santa Catalina). On Santa Catalina Island, California myotis were discovered roosting in buildings at Emerald Bay, Toyon Canyon, Gallagher's Landing, the airport, and Middle Ranch. They were also found under the tiles at the Wrigley Memorial in Avalon Canyon (Brown and Berry 2002). On Santa Cruz Island, this species forms small maternity colonies in the Stanton Ranch buildings in the Central Valley, the Nature Conservancy buildings, the attic of Christi Ranch on the west end of the island (Brown 1980; Brown personal observation), and the buildings at Scorpion Anchorage on the east end (Brown and Berry 2007). On Santa Rosa Island, G. Fellers and C. Drost mist-netted a lactating female in Lobo Canyon on 29 June 1989, and a bat research group observed small bats exiting from the barns in 2003 (C. Drost personal communication). P.E. Brown and W.E. Rainey found guano attributable to small myotis in the same barns in October 2016. Echolocation signals $(50 \mathrm{kHz})$ probably attributable to California myotis were frequently recorded on Santa Rosa Island in 2003 (C. Drost personal communication) and 2016 (Rainey personal observation).

In 1894 and 1897, eleven specimens of California myotis were collected from San Clemente Island, including 5 females in May, June, and August (USNM 61682, 92065-92068), which could indicate a possible breeding colony. O'Farrell and Hass (2002) conducted visual, mist-netting, and acoustic surveys in March, May, and October. California myotis were detected acoustically in multiple locations, but only one male was captured. A current breeding population on the island cannot be verified.

A single male California myotis was collected in a building on San Nicolas Island in 1943 (Von Bloeker 1967). Several mist-netting or short-term acoustic surveys between 2008 and 2015 on San Nicolas Island by Brown and Rainey failed to locate any evidence of this species in buildings. A long-term acoustic monitor at the sewage ponds detected several nights of California myotis activity in fall
2016. The absence of similar detections in prior years of monitoring suggests a recent arrival rather than failure to detect a resident population present since the 1943 record. Reports of small bats observed flying at dusk on Santa Barbara, Anacapa, and San Miguel Islands (Von Bloeker 1967, Brown 1980) are probably California myotis, although no shortor long-term acoustic surveys have been conducted on these islands.

\section{Townsend's Big-eared Bat (Corynorhinus townsendii)}

A key factor in the distribution of Townsend's big-eared bat across its range is the availability of undisturbed cave-like roosting habitat (Pierson and Rainey 1996a). Population concentrations occur in areas with substantial surface exposures of cavity-forming rock (e.g., limestone, sandstone, gypsum, or volcanic rock) and in old mining districts (Graham 1966, Genter 1986, Perkins and Levesque 1987, Perkins et al. 1994). From the perspective of many bat species, old mines are cave habitat, and mines are now sheltering many large colonies (Brown et al. 1992, Tuttle and Taylor 1994). Abandoned or little-used portions of buildings also provide roosting habitat for Townsend's big-eared bat, such as at Scorpion Cove on Santa Cruz Island (Brown et al. 1994) and at Point Reyes National Seashore (Fellers and Pierson 2002). This species is adept at avoiding mist nets and usually emits faint echolocation signals (Corcoran and Conner 2017). It is often not detected in acoustic surveys except near roosts, so locating a roost is the best method for verifying the presence of this species. Echolocation signals of Townsend's big-eared bats have been recorded both on Santa Cruz and Catalina Islands near known roosts (Brown and Berry 2002, 2007; C. Drost personal communication, J. King personal communication).

Santa Cruz and Catalina Islands are currently the only islands with confirmed breeding populations of Townsend's big-eared bats. Historically, specimens from 1943 of single males were collected from San Clemente (shallow cave near Wilson's Cove) and San Nicolas Islands (Von Bloeker 1967). G. Fellers and C. Drost (personal communication) saw a solitary Townsend's big-eared bat in a shallow cave near Lobo Canyon on Santa Rosa Island on 16 June and 4 July 1989, but they were 


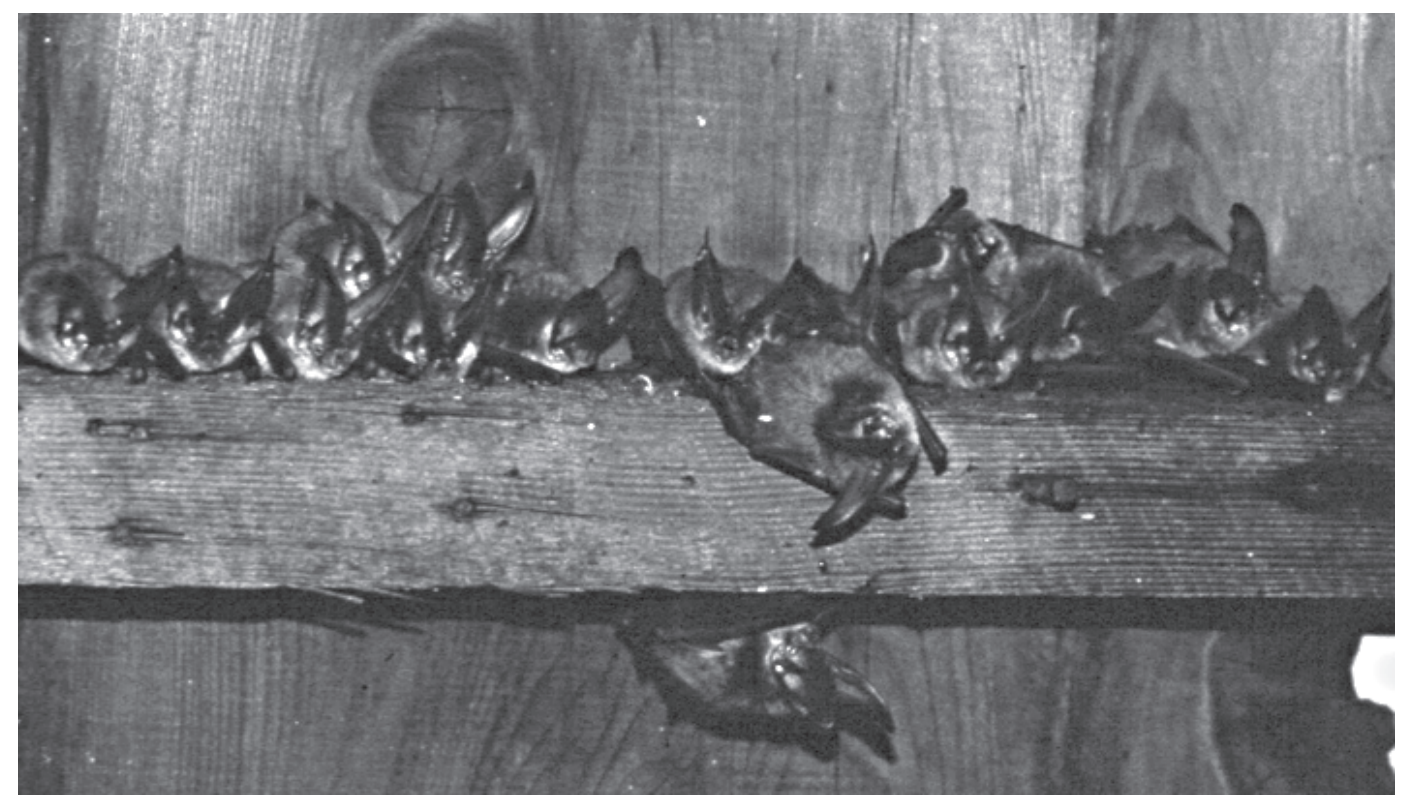

Fig. 2. Maternity colony of Townsend's big-eared bats (Corynorhinus townsendii) in the attic of the "bakery" at Scorpion Ranch, Santa Cruz Island, in August 1992.

unable to capture the bat. On Santa Catalina Island in March 1941, Von Bloeker captured a male and female Townsend's big-eared bat at Middle Ranch and White's Landing. The presence of both males and females on the island was evidence for a possible breeding population. A moribund female Townsend's big-eared bat was discovered on 27 June 2001 at Middle Ranch (Brown and Berry 2002). Catalina Island is unique among the Channel Islands in that there are many abandoned mines on the island. Most recent records for this species have been in mines, including a colony of about 8 bats in the Silver Peak Mine in Boushay Canyon (Brown and Berry 2002). Many mines are now gated to allow bat access and prohibit human intrusion, and bat use is increasing (J. King personal communication).

Historically, a colony of over 300 Townsend's big-eared bats inhabited a building on Santa Cruz Island at Prisoners Harbor. Unfortunately, 246 of the bats were collected as museum specimens in the 3 decades prior to the removal of the buildings in 1964 (Von Bloeker 1967, Brown 1980). In 1991, a maternity colony of Townsend's big-eared bats was discovered in the attic of the "bakery" at the adobe at Scorpion Ranch on the east end of Santa Cruz Island (Fig. 2) before the ranch was acquired by the National Park Service (NPS). Currently, this is the only colony of Townsend's big-eared bats known on Santa Cruz Island. The colony may have relocated from Prisoners Harbor after disturbance from collectors and building removal or it may represent a separate population on the east end of Santa Cruz Island (Brown et al. 1994). In late July or August between 1992 and 2007, an average of 136 adults and volant juveniles exited the bakery after dark. Ultrasonic detectors placed near the bakery and the equipment storage yard recorded echolocation signals of Townsend's big-eared bats and California myotis (Drost 2003, Brown and Berry 2007). Radiotelemetry showed that the bats living in the bakery did not forage in the exotic vegetation close to the roost. Instead they traveled several miles inland to feed among the remaining native oaks and ironwood trees (Brown et al. 1994).

The Scorpion Ranch adobe has been renovated to serve as an NPS visitor center, and, at times, maintenance activities and human disturbance have displaced these bats. Alternative roosts temporarily occupied by the bats after disturbance are 2 small caves (enlarged by ranchers) between the adobe and Scorpion Anchorage, though neither of these caves is 
as warm as the bakery and both can be entered by visitors to the island. Warm roost temperatures are important for successful development of the juveniles during the maternity season from May to July (Brown and Berry 2007). On 4 August 2013, a biologist looking for storm-petrels in a sea cave at Cavern Point near Scorpion Anchorage observed and photographed a cluster of 30-35 Townsend's big-eared bats ( $\mathrm{J}$. Howard personal communication).

Protecting this sensitive species from roost disturbance is key to their persistence on Santa Catalina and Santa Cruz Islands as human visitation increases. Townsend's bigeared bats were at one time common along coastal southern California (Krutzsch 1948), but the 2 island populations are among the few that now remain. Habitat destruction and human disturbance are responsible for substantial population declines throughout the state (Pierson and Rainey 1996a). Townsend's big-eared bats are usually so sensitive to human disturbance that a single entry into a maternity roost can cause a colony to abandon or move to an alternate roost, with females sometimes leaving their nonvolant young behind (Graham 1966, Stihler and Hall 1993; Brown personal observation). Townsend's bigeared bats have one young per year (Pearson et al. 1952), and, if the individual survives the first year, it may live over 20 years. Not all females give birth each year, and every young born will not survive, especially during times of drought. Therefore, populations are slow to recover from declines. Inappropriate behavior on the part of well-intentioned researchers and others (i.e., entry into maternity roosts, capturing animals in roosts, and building maintenance during the maternity season) can also contribute to population declines, such as the one that occurred at Prisoners Harbor and at Scorpion Ranch on Santa Cruz Island (Brown 1980, Brown et al. 2008).

\section{Pallid Bat \\ (Antrozous pallidus)}

This long-eared, large-eyed, golden-brown bat is the largest resident bat on Santa Cruz Island. Between 1939 and 1948, 127 specimens were collected from the barns and the old winery building in the Central Valley. In August 1939, Ed Stanton (prior owner of Santa Cruz Island) told Von Bloeker (1967) that the colony in the winery produced over 2 tons of bat guano that was used as fertilizer for the gardens on the island. Pallid bats are social animals, with an array of audible communication sounds (Brown 1976) that are often a better indicator of their presence than echolocation signals. This species apparently locates prey primarily by listening to preyproduced sounds (Bell 1982), although it uses echolocation to navigate, assess habitat, and presumably capture flying prey. Between foraging bouts, pallid bats congregate in night roosts which are most evident in buildings. There they deposit guano and the culled remains of large prey such as scorpions, katydids, sphinx moths, Jerusalem crickets (Stenopelmatus fuscus), and beetles (Orr 1954, Barbour and Davis 1969, Hermanson and O’Shea 1983).

The only pallid bat captured on Santa Catalina was a female roosting in a house in Avalon in May 1935 (Von Bloeker 1967). For a typically colonial species, finding an isolated female during the breeding season is unusual, and there may have been more animals present than were collected. This species is expected on Santa Catalina Island, because both the roosting and foraging habitat used on the adjacent mainland are represented. On Catalina, the bats could be roosting during the day in rock crevices where they are invisible, although Brown and Berry (2002) expected them to roost at least at night in the buildings of Middle Ranch or Rancho Escondido. As mentioned, the species makes itself known to people by night-roosting in buildings and leaving guano and scattered insect remains below. Elytra of ten-lined June beetles (Polyphylla decemlineata), a favored pallid bat food, were found along with the bat's distinctive guano in a shallow mining prospect below Lower Cottonwood Canyon reservoir. Pallid bat guano was also found in the basement at Banning House at the Isthmus and in a propane storage bunker northwest of the Isthmus (Brown and Berry 2002). On Santa Rosa Island, Brown (personal observation) found pallid bat guano and large beetle elytra at a Cold War-era military installation just before it was demolished by the National Park Service in 1993. Long-duration acoustic surveys and mist-netting could assess the current presence of this species on Santa Rosa Island. 


\section{Mexican Free-tailed Bat \\ (Tadarida brasiliensis mexicana)}

Mexican free-tailed bats can forage over large areas each night. They have been known to fly 50 miles from large day roosts in Texas to feeding areas, often ascending over 5000 feet above the ground before they disperse to feed (Davis et al. 1962, McCracken et al. 2008, Gillam et al. 2009). They undertake long seasonal migrations, often more than a thousand miles, to overwinter in southern Mexico and are adapted for overwater dispersal and island colonization. They often roost in crevices in cliff faces or man-made structures (Barbour and Davis 1969, Wilkins 1989). Acoustically, Mexican free-tailed bats appear to be the most ubiquitous species in most areas of coastal Southern California, in part due to their loud, relatively low-frequency search phase echolocation signals that are detectable over long distances (Simmons et al. 1978).

Currently, presence of this species has been confirmed on 5 of the California Channel Islands (Santa Cruz, Santa Rosa, Santa Catalina, San Nicolas, and San Clemente). Historically, specimens of male Mexican free-tailed bats were collected on Santa Cruz Island in 1939, and a female was captured on San Clemente Island in 1943 (Von Bloeker 1967, Brown 1980). Mexican free-tailed bats roost with pallid bats and myotis in the horse barn at Stanton Ranch on Santa Cruz Island. The barn does not appear to house a breeding colony, as all bats captured there have been male. Although some bats can be found in the barn throughout the year, the largest numbers are observed in early fall, a time that coincides with migration of this species in mainland California (Brown personal observation). Mexican free-tailed bats often fly high and are not captured in mist nets in proportion to their acoustic activity, although several males were captured over the stream in Cañada del Puerto in September 1978 (Brown 1980) and July 2017 (Brown and Rainey personal observations). In September and October 2016, two male Mexican free-tailed bats were found in the buildings at Middle Ranch on Santa Catalina Island (J. King personal communication). On San Miguel Island, a scientist studying marine mammals described a bat to C. Drost (personal communication) that may have been a Mexican free-tailed bat roosting at the research building, although no photos were taken.
The first acoustic survey on Santa Catalina in April and October 2000 by Brown and Berry (2002) detected this species in 2 locations. On Santa Rosa Island in October 2003, a research team organized by C. Drost (personal communication) recorded an echolocation call sequence of a Mexican free-tailed bat in Windmill Canyon. In October 2016, W.E. Rainey recorded call sequences of this species at Windmill and Water Canyons and at a water-filled stock tank near the barns at Beecher's Bay. A long-term acoustic monitor on San Nicolas Island has detected Mexican free-tailed bats in migratory pulses lasting several nights (Fig. 3A), principally in the fall and winter (Rainey and Brown 2017). Mexican free-tailed bats will probably be detected on all islands, especially during fall migration, if acoustic monitoring equipment is more widely deployed. Among western North American bats, this species is noted for an unusually varied array of echolocation calls (e.g., Gillam et al. 2009). Though some calls are diagnostic, the vocal repertoires of Mexican free-tailed bats overlap with other species calling near $25 \mathrm{kHz}$, such as big brown and silver-haired bats (Ommundsen et al. 2017)

\section{Long-eared Myotis (Myotis evotis)}

The long black ears of this species extend 7 to $10 \mathrm{~mm}$ beyond the nose when the ears are laid forward. Throughout its range, the long-eared myotis is usually associated with forested areas where it roosts in tree hollows and under exfoliating bark, in mines and caves, and in crevices in rocks and buildings (Manning and Jones 1989). This bat is not currently known to occur along the coast in Los Angeles or Ventura Counties. Two males were taken from Santa Cruz Island in August 1939 and December 1941 (Von Bloeker 1967). The only specimen from Catalina was a male taken by J.C. Von Bloeker from under the corrugated roof of an old building at White's Landing in October 1941. None were seen or captured during the Brown and Berry 2000-2001 survey on Santa Catalina, although several echolocation signals characteristic of long-eared myotis were recorded in July 2001 near Avalon (Brown and Berry 2002). With no female specimens, it appears that this species has not established a breeding colony on any of the islands. 


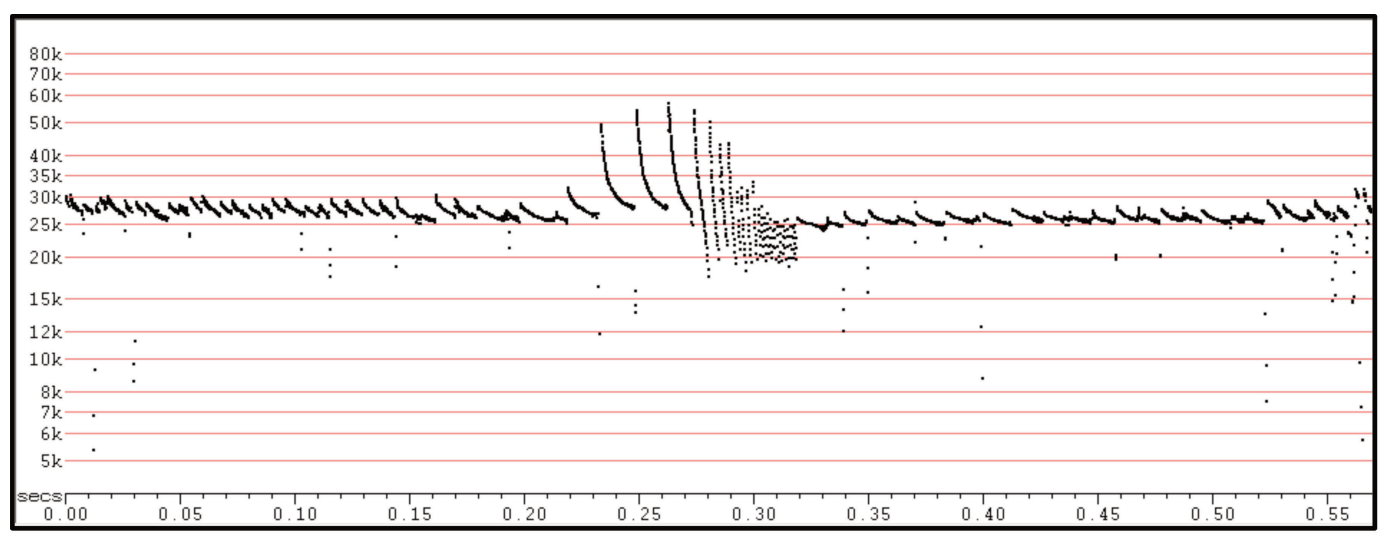

A. Mexican free-tailed bat (June 2, 2016)

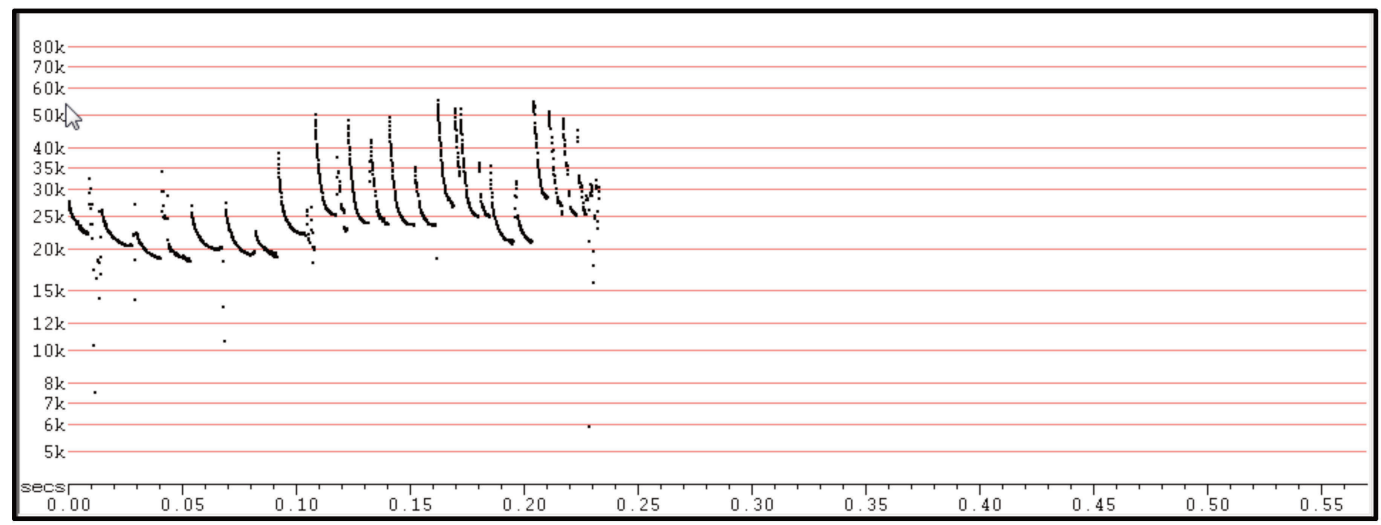

\section{B. Hoary bat (October 31, 2015)}

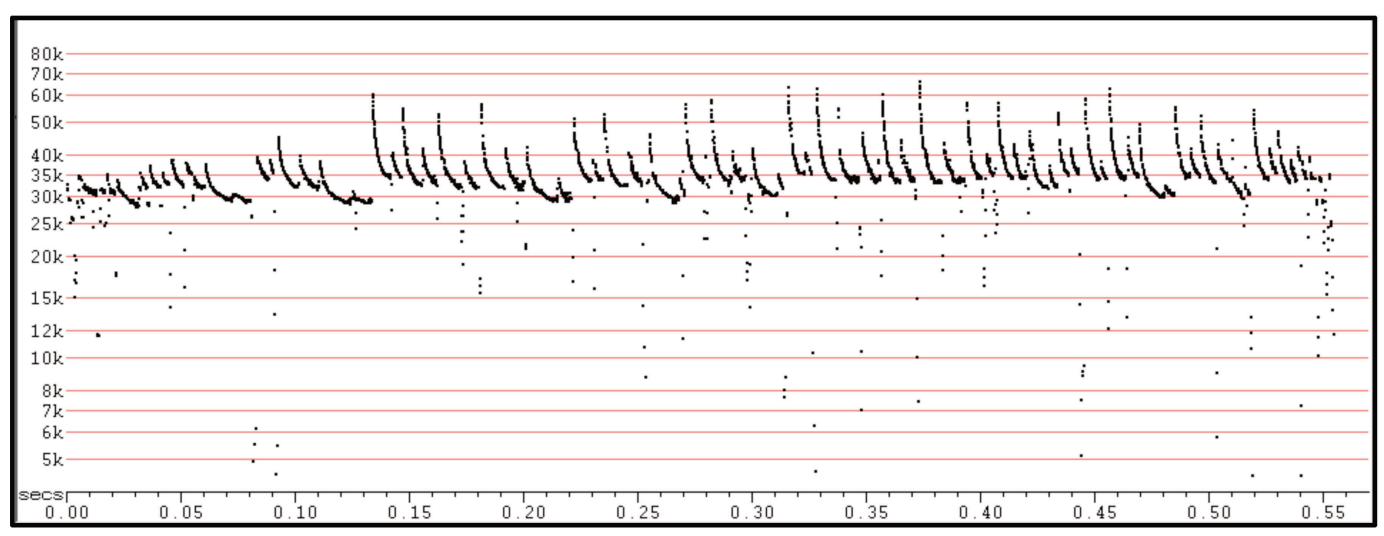

C. Western yellow bat (September 13, 2015)

Fig. 3. Time versus log frequency plots of call sequences from the long-term detector on San Nicholas Island (Fig. 1A). Sequences are compressed to display more pulses by removing the time between calls. A, Mexican free-tailed bat (Tadarida brasiliensis); B, hoary bat (Lasiurus cinereus); C, western yellow bat (Lasiurus xanthinus). 


\author{
Fringed Myotis \\ (Myotis thysanodes)
}

In California, the fringed myotis occupies a wide range of habitats from desert scrub to high-elevation coniferous forest, and it roosts in mines, buildings, caves, trees, and rock crevices (Barbour and Davis 1969). The diet of the fringed myotis appears to vary across its geographic range, but beetles and moths predominate (Brown personal observation; O'Farrell and Studier 1980). This myotis species can be distinguished from all other California bats by a well-developed fringe of hair on the posterior edge of the tail membrane. The species has relatively large brown ears and could be confused with the long-eared myotis, which has longer black ears and no fringe on the tail membrane (Barbour and Davis 1969). The only historic specimen for the California Islands was a female captured by von Bloeker (1967) at Wilson's Cove on San Clemente Island in August 1943. Subsequently, a male fringed myotis was mist netted over the stream near the University of California Research Station on 22 July 1988 (Brown et al. 1994). A bat videotaped under the bridge in Middle Canyon on Santa Catalina appeared to have long brown ears, but it was not captured, so the tail membrane fringe could not be evaluated. Acoustic signals recorded on 2 occasions near the bridge appear consistent with fringed myotis (Brown and Berry 2002). There is no evidence that this species has established a breeding colony on any island.

\section{Big Brown Bat \\ (Eptesicus fuscus)}

This ubiquitous species occurs in most habitat types in all 48 contiguous United States (Barbour and Davis 1969, Kurta and Baker 1990). However, it has not been found on any of the California Channel Islands except for a torpid female found in December 1943 in the attic of the old building at Prisoners Harbor on Santa Cruz Island (Von Bloeker 1967, Brown 1980). Mainland populations appear to be sedentary and exhibit high roost fidelity. The 20 or more miles of ocean may be an effective barrier to dispersal. However, if the big brown bat did arrive, it could probably become established on Santa Cruz and Santa Catalina Islands. Big brown bats consume moths and beetles, many of which are agricultural and forest pests (Whitaker et al.
1997), making the this species one of the most beneficial insectivorous bat species. Individuals readily roost in manmade structures, often in association with myotis and Mexican free-tailed bats. As mentioned, some echolocation signals of big brown bats are similar to those emitted by Mexican free-tailed bats.

\section{Hoary Bat \\ (Lasiurus cinereus)}

Hoary bats migrate both altitudinally and latitudinally and can travel over a thousand miles in the spring and fall (Grinnell 1918, Dalquest 1943, Cryan 2003). This species is capable of very long overwater flights. It has colonized the Hawaiian Islands twice (Russell et al. 2015) and also the Galapagos Islands, the latter perhaps recently (McCracken et al. 1997). Tenaza (1966) observed up to 12 migrant hoary bats per day roosting in the (only) 3 trees on South Farallon Island (20 miles over water from Point Reyes) in August and September 1965. Cryan and Brown (2007) analyzed a 38 -year record of daily fall bat counts from the same site with a maximum of 121 bats/month $(\bar{x}=5)$. Both papers report much smaller counts of spring migrants (Tenaza 1966, Cryan and Brown 2007).

In the spring of 1974, Dr. Carey Stanton found a hoary bat lying in the dust near the ranch buildings on Santa Cruz Island. Fearing that it was rabid, he killed the animal, which was then identified by Dr. Lyndal Laughrin (Director of the UCSB Research Station). The bat was sent to the California Department of Public Health for rabies testing (the results were negative), but unfortunately the specimen was lost. Brown (1980) mist-netted a male hoary bat over the stream in Cañada del Puerto on 25 September 1978. At noon on 11 October 1974, Dr. H. Lee Jones and 15 ornithologists located a hoary bat on the ground in the ice plants on Santa Barbara Island. Several pictures were taken before the animal aroused and flew away, landing again in some ice plants. On 4 November 1987, C. Drost collected a fresh Barn Owl pellet in Middle Canyon of Santa Barbara Island that contained a hoary bat skeleton (SBMNH 3923).

With the advent of acoustic recording, signals of hoary bats were recorded on Santa Catalina at White's Landing and Toyon Canyon in October 2001 (Brown and Berry 2002). Acoustic records documented the presence 
of a hoary bat in Water Canyon on Santa Rosa Island on 15 October 2003 (C. Drost personal communication) and 7 October 2016 (Brown and Rainey personal observations). Researchers working with C. Drost (personal communication) recorded the echolocation signals of a hoary bat near the Stanton Ranch on 29 September 2003. After installing 2 long-term Anabat detectors (Titley Scientific, Columbia, MO) in late July 2017 in the Central Valley of Santa Cruz Island, we have recorded hoary bats during most months. A long-term acoustic detector at the sewage pond on San Nicolas Island has recorded peak hoary bat activity in a short period in mid-October (Figs. 1A, 3B), with some call sequences in November and a few in March (Rainey and Brown, 2017). Most captures and acoustic records of hoary bats on the Channel Islands are in the early to mid-fall during known times of migration. As suggested by aggregated arrivals on the Farallon Islands (Tenaza 1966) and several historical observations of large flocks of diurnally migrating lasiurines (e.g., Mearns 1898), hoary bats could be migrating in flocks. Long-term acoustic detectors will probably document this bat on all the Channel Islands, especially during times of migration. Acoustic recordings in the Santa Monica Mountains to the east of Santa Cruz Island show the presence of resident hoary bats between March and September (Brown and Berry 2005).

\section{Western Red Bat \\ (Lasiurus blossevillii)}

This smaller relative of the hoary bat is distinguished by its coppery red fur, which covers most of the wing and tail membranes. Like the hoary and silver-haired bats, the western red bat is typically a noncolonial, migratory, foliage-roosting species that on the mainland relies heavily on mature sycamore and cottonwood riparian habitat for both roosting and foraging habitat (Shump and Shump 1982, Pierson et al. 2006, 2011). Krutzsch (1948) considered its presence in San Diego County directly influenced by the availability of suitable trees and shrubs for roosting. Day roosts were in a variety of native and exotic trees and in shrubs with foliage sufficiently dense to provide suitable hiding places. During a survey of the Santa Monica Mountains in sycamore riparian habitat, a lactating red bat was captured over a stream in July 2004, and males were captured in August and November. Half of all acoustic detections were recorded between July and September, evidence that this species is a year-round resident in coastal California near the Channel Islands (Brown and Berry 2005).

A male red bat was mist-netted over the swimming pool at the Stanton Ranch on 23 September 1978, during a period when warm Santa Ana winds were blowing off the mainland (Brown 1980). The male hoary bat mentioned previously and 4 Mexican free-tailed bats were also collected during this time of fall migrations. A red bat was seen on the east end of Santa Cruz Island flying in the native oak and ironwood forest during the August 1992 telemetry study (R. Berry personal observation). On 30 September 2003, biologists working with C. Drost (personal communication) mist-netted a female red bat over the stream at Cañada del Puerto and recorded echolocation signals. On 26 July and 30 July 2017 , juvenile red bats were mist-netted over the stream in Cañada del Puerto, just below the Stanton Ranch, making this the first record of reproduction for this species on the Channel Islands (Brown and Rainey personal observations). We installed 2 passive long-term acoustic detectors on Santa Cruz Island in late July 2017 and recorded red bats every month through January 2018, except in December 2017, with detections most frequent in late summer and early fall (Fig. 4C). Passive acoustic recording equipment on San Nicolas Island has recorded call sequences of red bats in October 2012 and September 2015 (Rainey and Brown 2017). On 29 April 2017, Dr. John Orrock (University of Wisconsin, Madison, personal communication) observed a red bat constantly circling the pond inland of Cuyler Harbor on San Miguel Island at 13:30 (early afternoon). This event followed 3 days of very strong winds.

\section{Silver-haired Bat \\ (Lasionycteris noctivagans)}

The silver-haired bat, another migratory species, is associated with forested areas throughout North America (Hall 1981, Kunz 1982, Cryan 2003), where it roosts colonially in tree hollows or under loose bark. Although the species is more typically found in northern California and the Sierra Nevada, a male was mist-netted on 14 June 1974 over the stream 


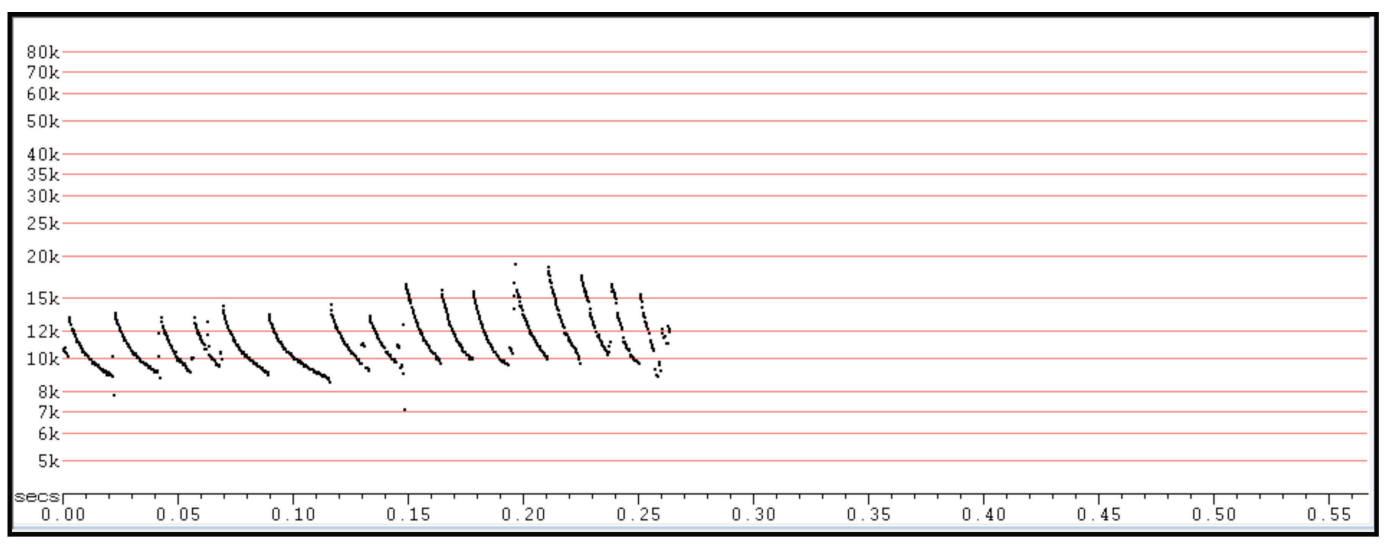

A. Western mastiff bat (September 19, 2017)

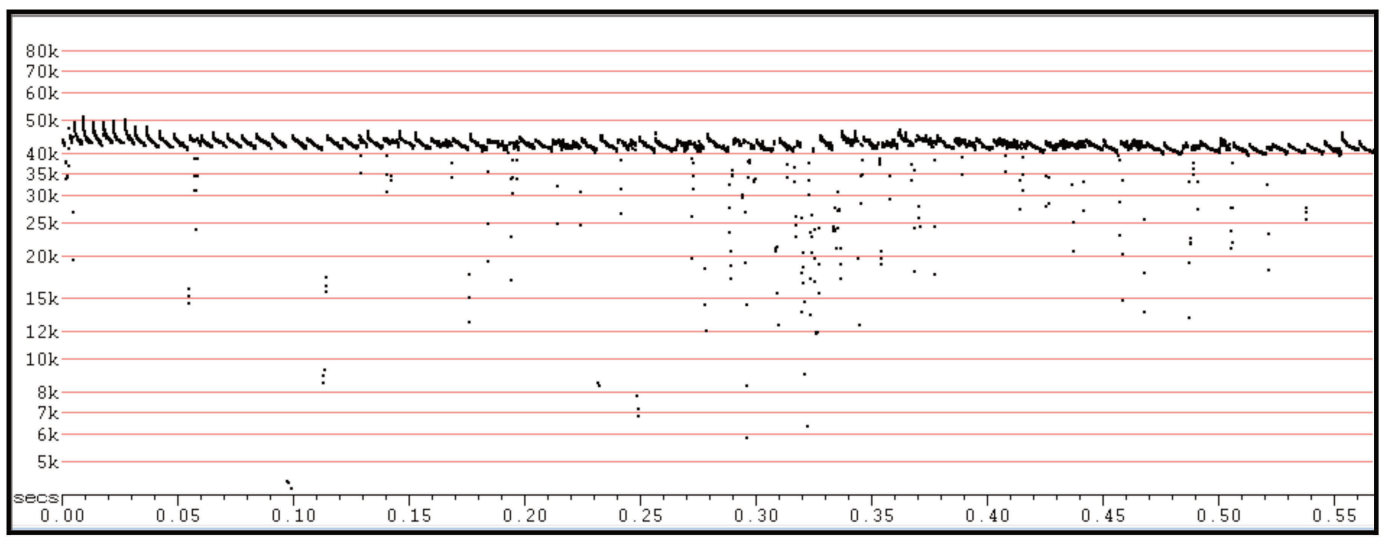

B. Canyon bat (August 27, 2017)

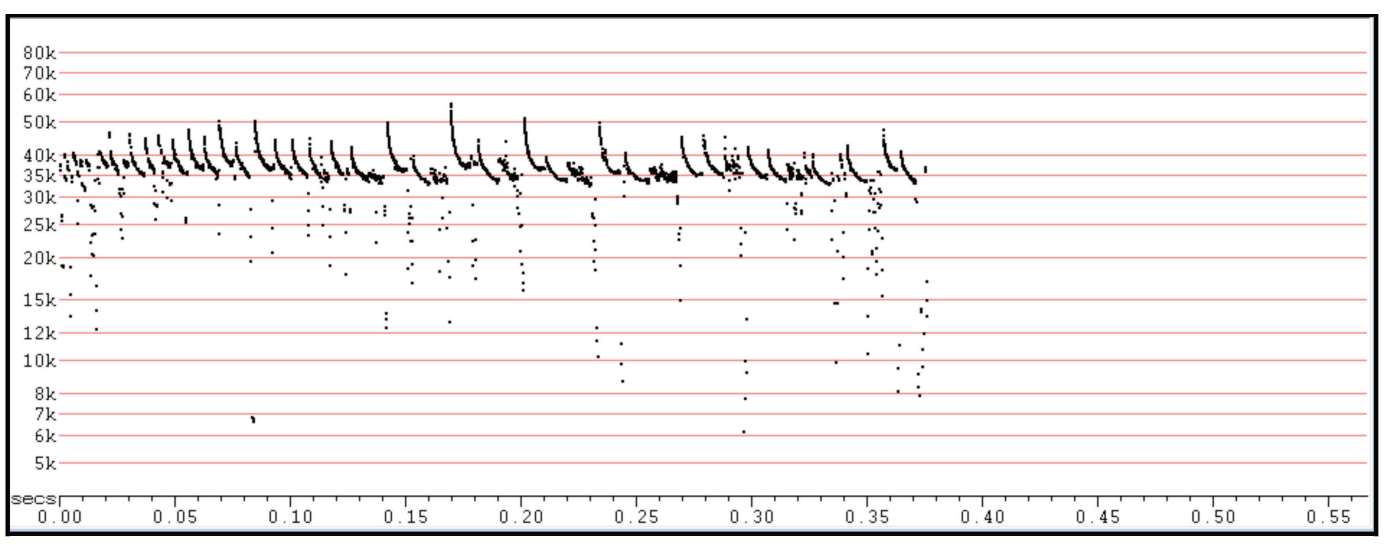

C. Western red bat (August 3, 2017)

Fig. 4. Time versus log frequency plots of compressed call sequences from long-term detectors on Santa Cruz Island: A, western mastiff bat (Eumops perotis); B, canyon bat (Parastrellus hesperus); C, western red bat (Lasiurus blossevillii). 
in Cañada del Puerto on Santa Cruz Island (Brown 1980). Constantine (1998) examined several specimens submitted to the California Department of Public Health for rabies testing between 1973 and 1997 from Los Angeles County, including Santa Monica. This species could be expected to occur sporadically on the Channel Islands, especially during migratory periods. The silver-haired bat echolocation repertoire includes calls that could be confused with some emitted by Mexican freetailed bats and big brown bats.

\section{Acoustic Records \\ Western Yellow Bat \\ (Lasiurus xanthinus)}

Previously recognized as a subspecies of the southern yellow bat (Lasiurus ega), the western yellow bat was separated based on genetic data (Baker et al. 1988, Morales and Bickham 1995). The geographic distribution of the western yellow bat is largely in Mexico and Central America and extends north into the southwestern United States (southern California, Nevada, Arizona, New Mexico, and west Texas [Kurta and Lehr 1995]). Like other Lasiurus species, the western yellow bat roosts primarily in trees and typically has been found day-roosting in the dense skirts of pendant dried fronds on the trunks of palms (O'Farrell et al. 2004). The first record in the United States was from Palm Springs in 1945 (Constantine 1946). There is evidence suggesting that this species has expanded its range in response to palm plantings. Constantine (1998) reported the geographic locations of 214 western yellow bats (identified after rabies testing in California) that extended the species' range north and west into southeastern Los Angeles County and adjacent areas. Records near or on the Pacific Coast in Orange and San Diego Counties are in more mesic habitat than had previously been expected for this species.

During Bureau of Reclamation surveys of bats in vegetative restoration areas along the Lower Colorado River, western yellow bats have been mist-netted frequently in summer. Radiotelemetered individuals captured foraging in restored cottonwood riparian habitat were tracked to roosts in palm trees (Calvert 2010; Calvert personal communication). Longterm acoustic monitoring at multiple habitat restoration sites along the river has shown that the species is recorded predominantly in March through November with only scattered winter detections (A. Calvert personal communication). Strongly seasonal activity and the documented migration of related species (western red and hoary bats) suggest that western yellow bats are also latitudinal migrants.

One of the most interesting acoustic records of a new bat species for the California Channel Islands occurred when multiple diagnostic western yellow bat call sequences were recorded on 10 nights between 13 September and 1 October 2015 by a long-term acoustic monitor at the sewage ponds on San Nicolas Island (Figs. 1A, 3C; Rainey and Brown 2017). The timing is consistent with the seasonal pattern of detections at San Nicolas Island for previously recognized seasonal migrants (western red, hoary, and Mexican free-tailed bats). There were no prior western yellow bat capture or acoustic records from other Channel Islands (Brown 1980), but erratic seasonal occurrences may derive from weather conditions such as Santa Ana winds displacing migrating bats, along with warblers and other land birds (Lethaby et al. 2012). Like the Farallon Islands, persistence of migrating or vagrant bats on San Nicolas Island for more than a few days seems unlikely. A record of a healthy southern yellow bat (Lasiurius ega) landing on a vessel located 208 miles off the Argentine coast (Van Deusen 1961) suggests substantial long-distance migration in that species as well. A long-term acoustic monitor at Naval Base Ventura County Point Mugu (NBVC) recorded one western yellow bat sequence on 24 August 2015, which is within the seasonal window for fall migration of other lasiurine species (Rainey and Brown 2017).

\section{Western Mastiff Bat \\ (Eumops perotis)}

Western mastiff bats belong to the freetailed bat family Molossidae, and this species is the largest bat found in North America. They have a 2 -foot $(60-\mathrm{cm})$ wingspan and large bonnet-like ears, which extend forward over the eyes and are connected at the midline (Barbour and Davis 1969, Best et al. 1996). Western mastiff bats are found in a variety of biotic environments from low desert scrub to chaparral, oak woodland, and ponderosa pine. In California, western mastiff bats appear to feed primarily on moths (Lepidoptera) but 
may also take beetles and crickets (Whitaker et al. 1977). Abiotic habitat components appear to determine their distribution as they roost predominantly in crevices in fractured hard rock cliff faces (e.g., granite, sandstone, or columnar basalt) or exfoliating granite boulders (Dalquest 1946, Krutzsch 1955, Vaughan 1959) but also utilize cracks in buildings (Howell 1920, Barbour and Davis 1969). All roosts in California examined by Pierson and Rainey (1996b) were in crevices at least $3.5 \mathrm{~m}$ above the ground.

Unlike Mexican free-tailed bats that may undertake long seasonal migrations, western mastiff bats appear to move relatively short distances seasonally. Although capable of lowering their body temperatures for short periods of time, they do not undergo prolonged hibernation and may be periodically active throughout the winter (Leitner 1966). In Southern California, mastiff bats have been detected at all seasons, although they may change roost sites (Howell 1920, Krutzsch 1943, 1955, Barbour and Davis 1969). The 113 specimens curated in the Los Angeles County Museum of Natural History were taken during all months throughout the Los Angeles Basin.

Western mastiff bats emit audible echolocation calls and can be detected flying throughout the night. These strong, fast fliers cover an extensive foraging area in an evening. The species has been heard in open desert, at least 15 miles from the nearest possible roosting site (Vaughan 1959), and similar movements have been obtained by radiotracking (Siders et al. 1999). Often multiple animals are detected together, and this species may travel or forage in groups (E. Pierson personal communication, Brown personal observation). Mastiff calls were recorded at Naval Base Ventura County Point Mugu in most months, excluding late fall and winter (Rainey and Brown 2017). This species was frequently detected during the Santa Monica Mountains surveys in all months, with the most recordings in July and August (Brown and Berry 2005). Several researchers heard the distinctive calls in August 1992 near Scorpion Ranch on the east end of Santa Cruz Island (Brown et al. 1994). After the installation of long-term acoustic detectors on Santa Cruz Island, a single western mastiff call sequence was recorded on 19 September 2017 (Fig. 4A). Given the potential range of nightly foraging flights, the bats could be acoustically detected on most of the Channel Islands, even if they are not resident.

\section{Canyon Bat \\ (Parastrellus hesperus)}

The canyon bat is the smallest of all North American bats and can be distinguished from myotis species by the club-shaped ear tragus (Barbour and Davis 1969). The common name refers to its association with rocky canyons and outcrops (usually at elevations below $2000 \mathrm{~m}$ ), where it roosts in small crevices (Stager 1943, Cross 1965). Individuals emerge early in the evening, often before sunset, and may be active after sunrise. In desert areas, canyon bats are often the first bats captured in the evening in mist nets set over water sources (O’Farrell and Bradley 1970). Stomach content analysis suggests that they feed on small swarming insects such as flying ants and mosquitoes (Hayward and Cross 1979). During cooler winter months, canyon bats hibernate in rock crevices, although on warm winter days, they may emerge to forage during the day. Acoustically the canyon bat is one of the more easily distinguishable western U.S. species (Rodhouse et al. 2011).

Although canyon bats were commonly captured and detected acoustically in the Santa Monica Mountains (Brown and Berry 2005), they had not been documented on the Channel Islands. With the advent of long-term acoustic monitoring on Santa Cruz Island in July 2017, this species was recorded (Fig. 4B) on several nights in August 2017 in Cañada del Puerto.

\section{Potential Bat Species on the California Channel Islands}

With long-term acoustic recording, the number of bats detected on the California Channel Islands will increase. Some bat species may be detected that are visitors to the islands, especially during migration and sporadic weather events. Year-round acoustic records could help to determine which species are residents, migrants, and vagrants. Capture of reproductive females or juveniles, or visual observation of maternity colonies is still necessary to verify breeding status on the islands. Of the 25 bat species known in California, the following 6 species may be encountered on the California Channel Islands (in addition to the 14 already confirmed). 


\section{Pocketed Free-tailed Bat \\ (Nyctinomops femorosaccus)}

This slightly larger relative of the Mexican free-tailed bat differs by having its ears joined at the midline (Constantine 1958, Kumirai and Jones 1990). Pocketed free-tailed bats are found at lower elevations in a variety of plant associations (Barbour and Davis 1969, Easterla 1973) and in proximity to roosting habitat in granite boulders, cliffs, or rocky canyons. In California, this species is associated primarily with creosote bush and chaparral habitats of Lower and Upper Sonoran life zones (Krutzsch 1948). A California coastal record of a male pocketed free-tailed bat was collected in Inglewood on 18 October 1994 (Constantine 1998). Krutzsch (1948) documented pocketed free-tailed bats in Southern California from March through August. However, recent records from late November suggest that the species overwinters in San Diego County (Pierson and Rainey 1996b; K. Miner personal communication).

When emerging from their roosts in the evening, pocketed free-tailed bats frequently make audible "chattering" communication calls (Krutzsch 1944, 1948, Pierson and Rainey 1996b; K. Miner personal communication, Brown personal observation). Individuals emit a relatively low-frequency echolocation signal that may be audible to people with good high-frequency hearing. Like Mexican freetailed and western mastiff bats, pocketed free-tailed bats can forage over a wide area and could fly to the closer Channel Islands from the mainland. For all species of freetailed bats, long-term acoustic monitoring would be the best method to determine their presence on the islands.

\section{Big Free-tailed Bat \\ (Nyctinomops macrotis)}

This larger relative of the pocketed freetailed bat is relatively rare in the United States, with a broad but patchy pattern of records across the southwestern states and scattered records of vagrants elsewhere (Barbour and Davis 1969, Milner et al. 1990). Preferred roosting habitat appears to be in crevices of cliffs and large boulders, the same as for the western mastiff bat (Corbett et al. 2008). There are few records from California and a significant proportion of those from the West Coast appear to be isolated urban area vagrants
(Constantine 1998). Like the western mastiff bat, the big free-tailed bat emits a characteristic low-frequency echolocation call that is audible to some humans and usable for identification (Pierson and Rainey 1996b). Big free-tailed bats have been collected near the California coast from San Diego to San Francisco (Constantine 1998; D. Stokes personal communication), including one from Santa Barbara on 27 November 1996. A male was found alive on a Scripps Research vessel anchored near San Clemente Island in late October 2000; it was delivered to a wildlife rehabilitation facility near San Diego and subsequently released (K. Miner and D. Stokes personal communication). A diagnostic call sequence of a big freetailed bat was recorded on 18 October 2012 at Naval Base Ventura County Point Mugu (Rainey and Brown 2015). A passive detector in the Central Valley of Santa Cruz Island recorded several low-frequency $(15-\mathrm{kHz})$ molossid sequences on 19-20 November 2017 which suggest big free-tailed bats rather than western mastiff bats. Fall migration during the Santa Ana offshore winds might bring this species close to the islands.

\section{Spotted Bat \\ (Euderma maculatum)}

Spotted bats are distinguishable from all other North American species by their unique coloration (3 dorsal white spots on a background of black fur) and their very large pinkish ears and matching pinkish wing membranes. Additionally, there is a white patch at the base of each ear (Barbour and Davis 1969). Spotted bats occur throughout much of western North America (Watkins 1977), and their range extends as far north as British Columbia (Woodsworth et al. 1981) and as far south as Durango, Mexico. They have been captured in a variety of habitats from desert scrub to montane coniferous forest (Findley and Jones 1965) at elevations from $57 \mathrm{~m}$ (170 ft.) below sea level at the Salton Sea (Grinnell 1910) to $3230 \mathrm{~m}$ (9700 ft.) above sea level (Reynolds 1981). The type locality of the spotted bat is at Piru, Ventura County, California (Allen 1891, Grinnell 1918).

For a long time, spotted bats were considered one of the rarest mammals in North America. However, this species emits distinctive low-frequency echolocation signals (audible to many humans), and recent surveys 
have expanded its range in many areas (Pierson and Rainey 1996b, 1998). During surveys in the Santa Monica Mountains National Recreation Area, Brown and Berry (2005) recorded spotted bats 4 times in June and August. Three of these call sequences were recorded at dusk, and the other within an hour after sunset, indicating a roost in the vicinity. The rocky cliffs in the western Santa Monica Mountains could provide the preferred roosting habitat. This species is a strong flier (Chambers et al. 2011), covering distances elsewhere that would allow it to reach the northern Channel Islands, where it may be detected acoustically.

\section{Small-footed Myotis \\ (Myotis ciliolabrum)}

The small-footed myotis has a wide range in western North America, including much of California, and frequently co-occurs with California myotis, which it closely resembles in size and appearance (Bogan 1974, Holloway and Barclay 2001). This crevice and treedwelling species forages early in the evening on a variety of small insects. While California and small-footed myotis can be difficult to separate in the hand, they are usually acoustically differentiable. A reproductive female small-footed myotis was mist-netted in the Santa Monica Mountains, and others were acoustically detected in most habitats throughout the year during that survey (Brown and Berry 2005). A few high-slope $40-\mathrm{kHz}$ call sequences assignable to this species were recorded at the long-term acoustic monitoring station on NBVC Point Mugu in July through September 2015 (Rainey and Brown 2017).

\section{Long-legged Myotis \\ (Myotis volans)}

The long-legged myotis is medium sized and recognized by short, rounded ears, long tibia, and dense fur on the underside of the wing membrane (Warner and Czaplewski 1984). It is often found in habitat associations similar to the ones where the fringed myotis and long-eared myotis are found. Roosts can be in caves, mines, tree hollows, and manmade structures. Although these bats are more common in forested areas and higher elevations, isolated bats could travel to the islands. In 1903 and 1907, two specimens were collected in Pasadena, California, and Dr. Ken Stager
(LACMNH) collected several females from a movie studio sound stage on 30 August 1933. However, no recent records have emerged for this bat in the Los Angeles area. Acoustically, long-legged myotis signals may resemble those of small-footed myotis.

\section{Mexican Long-tongued Bat (Choeronycteris mexicana)}

The Mexican long-tongued bat is associated with blooming agaves and columnar cacti from the southwestern United States through Central America (Barbour and Davis 1969, Arroyo-Cabrales et al. 1987), where it roosts in caves and mines. Most United States records are from southern Arizona; however, a small population is now established in coastal San Diego County, where individuals are found roosting in man-made structures and feeding on exotic blossoms, such as those of cereus cacti (D. Stokes personal communication). During the fall, many migratory species turn up outside their traditional range. A male Mexican long-tongued bat was found in Ventura on 15 November 1994 (Constantine 1998). A vagrant may someday be captured on the Channel Islands, most probably on San Clemente Island. The faint echolocation signals of this species make it difficult to detect acoustically.

\section{Conclusions}

Fourteen bat species (Table 1) have been documented on 7 of the 8 California Channel Islands between 1893 and 2017. Bats now represent $78 \%$ of native land mammals on the islands (Collins 2012). Bats, like birds, are preadapted by flight to reach and colonize islands. However, unlike birds, their small size and secretive, nocturnal nature make them difficult to observe and capture. Historically only 8 species from the 5 largest islands were verified as museum specimens prior to the initial use of mist-netting in the 1970s, when 3 more tree-roosting species were added (Von Bloeker 1967, Brown 1980). Currently, only 5 species are known to breed on one or more of the California Channel Islands: pallid bat, Townsend's big-eared bat, western red bat, Yuma myotis, and California myotis. Breeding can only be confirmed by identification of maternity colonies or capture of reproductive females or juveniles. 
A long-term acoustic monitoring station installed on San Nicolas Island in 2014 has documented transient bats, especially during fall migration. Western yellow bats were detected during brief periods in the fall of 2015 and 2016. Two long-term detectors placed in the Central Valley and upper end of Cañada del Puerto on Santa Cruz Island in late July 2017 have already recorded canyon bats and a western mastiff bat. Anacapa has no confirmed bat identifications, and only one migratory species (hoary bat) has been identified for Santa Barbara Island. A sighting in 2017 of a red bat on San Miguel Island is the best species confirmation for that island. Although recording echolocation signals is a powerful tool in documenting bat occurrence, several points need to be considered when interpreting acoustic data: some calls could be misidentified because there is overlap in call characteristics between species; bats emitting louder echolocation signals such as Mexican free-tailed bats will be detected at greater distances, while faint signals of "whispering" bats such as Townsend's big-eared bats may not be recorded; and the number of call sequences recorded is an index of bat activity that does not usually equate to the number of bats.

Echolocation calls recorded via bat detectors have verified 3 new bat species (western mastiff bat, canyon bat, and western yellow bat) for the Channel Islands and additional records of bat species for individual islands. Acoustic records have confirmed the continued occurrence on some of the islands of species known only from historic records. However, at least one species (big brown bat) has not been recorded on any island since a single specimen was captured on Santa Cruz Island in 1943, and 4 more species (fringed myotis, long-eared myotis; Townsend's big-eared bat; and Mexican free-tailed bat) are apparently not present now on one or more of the islands where they were historically captured (Von Bloeker 1967). More survey effort via acoustic recording or capture could add as many as 6 new bat species to the Channel Islands' records, as well as help to verify the continued presence on individual islands of species represented by historic records. The installation of longterm acoustic monitors on other islands will identify year-round bat residents and document regular migrants and rare vagrants.

\section{ACKNOWLEDGMENTS}

Funding for the acoustic monitoring station on San Nicolas Island was made possible by a grant from the Naval Base Ventura County Point Mugu (NBVC) under contracts to Tetra Tech. Without the support from Martin Ruane (NBVC), Kathryn Norris and Joshua Moore (Tetra Tech), the new San Nicolas Island records would not have been obtained. Dr. Tracy Allen (EME Systems, Berkeley, CA) designed the solar enclosure systems and generously provided advice and components. We are grateful to the following people for sharing unpublished information on Channel Island bat records: Paul Collins, Santa Barbara Museum of Natural History; Charles Drost, United States Geological Survey; Julie King, Catalina Island Conservancy; Karen Miner, California Department of Fish and Wildlife; and Drew Stokes, San Diego Natural History Museum. Chris Corben, Susan Broderick, and Drew Stokes reviewed selected call sequences for species identification. Jill Carpenter and Robin Mulligan provided field assistance in July 2017 on Santa Cruz Island. We are very appreciative of Dr. Lyndal Laughrin's help with installing the acoustic monitoring stations on Santa Cruz Island, and for exchanging the data cards. Special thanks go to Marla Daily of the Santa Cruz Island Foundation who shares her endless knowledge of and enthusiasm for the California Channel Islands, and who encouraged us to present this paper at the California Islands Symposium in Ventura in 2016.

\section{Literature Cited}

Ahlen, I., H.J. BaAgoe, and L. Bach. 2009. Behavior of Scandinavian bats during migration and foraging at sea. Journal of Mammalogy 90:1318-1323.

Allen, J.A. 1891. Description of a new species of bigeared bat, of the genus Histiotus, from southern California. Bulletin of the American Museum of Natural History 3:195-198.

Arroyo-Cabrales, J., R.R. Hollander, and J.K. Jones Jr. 1987. Choeronycteris mexicana. Mammalian Species 291:1-5.

Baker, R.J., J.C. Patton, H.H. Genoways, and J.W. BickHAM. 1988. Genic studies of Lasiurus (Chiroptera: Vespertilionidae). Occasional Papers, Museum of Texas Tech University 117:1-15.

Barbour, R.W., and W.H. Davis. 1969. Bats of America. University of Kentucky Press, Lexington, KY.

BELL, G.P. 1982. Behavioral and ecological aspects of gleaning by a desert insectivorous bat, Antrozous pallidus (Chiroptera: Vespertilionidae). Behavioral Ecology and Sociobiology 10:217-223. 
Best, T.L., W.M. Kiser, and P.W. Freeman. 1996. Eumops perotis. Mammalian Species 534:1-8.

Bogan, M.A. 1974. Identification of Myotis californicus and Myotis leibii in southwestern North America. Proceedings of the Biological Society of Washington 87:49-56.

Brigham, R.M., H.D.J.N. Aldridge, and R.L. Mackey. 1992. Variation in habitat use and prey selection by Yuma bats, Myotis yumanensis. Journal of Mammalogy 73:640-645.

Britzke, E.R., E.H. Gillam, and K.L. Murray. 2013. Current state of understanding of ultrasonic detectors for the study of bat ecology. Acta Theriologica $58: 109-117$.

Broderick, S.C. 2010. Response of tree-roosting bat species to riparian habitat development along the Lower Colorado River in Arizona and California [abstract]. Bat Research News 51:148.

BRown, P. 1976. Vocal communication in the pallid bat, Antrozous pallidus. Zeitschrift für Tierpsychologie 41:34-54.

Brown, P.E. 1980. Distribution of bats of the California Channel Islands. Pages 751-756 in D.M. Power, editor, The California islands: proceedings of a multidisciplinary symposium. Santa Barbara Museum of Natural History, Santa Barbara, CA.

Brown, P.E., AND R.D. BERRY. 2002. Bat survey of Catalina Island. Report prepared for the Catalina Island Conservancy. 20 pp.

Brown, P.E., AND R. Berry. 2005. Bat surveys and the development of monitoring protocol for Santa Monica Mountains National Recreation Area, April 2002 through July 2004. Report to National Park Service, Santa Monica Mountains National Recreation Area. $35 \mathrm{pp}$.

Brown, P.E., AND R. BerRy. 2007. Townsend's big-eared bat survey and management plan for Scorpion Ranch, Santa Cruz Island. Report to National Park Service, Channel Islands National Park. 10 pp.

Brown, P.E., R. Berry, and C. Brown. 1992. Abandoned mines as habitat for bats and other wildlife. Page 65 in Proceedings of the East Mojave Desert Symposium. Riverside, CA.

Brown, P.E., R. Berry, and C. Brown. 1994. Foraging behavior of Townsend's big-eared bats (Plecotus townsendii) on Santa Cruz Island. Pages 367-370 in W.L. Halvorson and G.J. Maender, editors, The Fourth California Islands Symposium: update on the status of resources. Santa Barbara Museum of Natural History, Santa Barbara, CA.

Brown, P.E., R.D. Berry, C. Schwemm, and T. Coonan. 2008. Townsend's big-eared bats on Santa Cruz Island: preserving historic structures as critical habitat for a rare species [abstract]. Paper presented at the 7th Channel Islands Symposium, Oxnard, CA. 5-8 February 2008.

Calvert, A. 2010. Post-development bat monitoring of habitat creation areas along the Lower Colorado River-2009 capture surveys. Lower Colorado River Multi-Species Conservation Program. Bureau of Reclamation, Lower Colorado Region, Lower Colorado River Multi-Species Conservation Program Office, Boulder City, NV. 26 pp.

Chambers, C.L., M.J. Herder, K. Yasuda, D.G. Mikesic, S.M. Dewhurst, W.M. Masters, and D. Vleck. 2011. Roosts and home ranges of spotted bats (Euderma maculatum) in northern Arizona. Canadian Journal of Zoology 89:1256-1267.
Collins, P.W. 2012. The native terrestrial vertebrate fauna of the Channel Islands: biogeography, endemism and extinctions. Paper presented at the 8th Channel Islands Symposium, Ventura Beach Marriott, Ventura, CA. 23-26 October 2012.

Constantine, D.G. 1946. A record of Dasypterus ega xanthinus from Palm Springs, California. Bulletin of the Southern California Academy of Science 45:107.

Constantine, D.G. 1958. Remarks on external features of Tadarida femorosacca. Journal of Mammalogy 39:39.

Constantine, D.G. 1998. Range extensions of ten species of bats in California. Bulletin of the Southern California Academy of Sciences 97:49-75.

Corbett, R.J.M., C.L. Chambers, and M.J. Herder. 2008. Roosts and activity areas of Nyctinomops macrotis in northern Arizona. Acta Chiropterologica $10: 323-329$

Corcoran, A.J., And W.E. Conner. 2017. Predator counteradaptations: stealth echolocation overcomes insect sonar-jamming and evasive-manoeuvring defences. Animal Behaviour 132:291-301.

Cryan, P.M. 2003. Seasonal distribution of migratory tree bats (Lasiurus and Lasionycteris) in North America. Journal of Mammalogy 84:579-593.

Cryan, P.M., AND A.C. Brown. 2007. Migration of bats past a remote island offers clues toward the problem of bat fatalities at wind turbines. Biological Conservation 139:1-11.

DALQuEST, W.W. 1946. The daytime retreat of a California mastiff bat. Journal of Mammalogy 27:86-88.

DALQuEST, W.W. 1943. Seasonal distribution of the hoary bat along the Pacific Coast. Murrelet 24:20-24.

Dalquest, W.W. 1954. Netting bats in tropical Mexico. Transactions of the Kansas Academy of Science $57(1): 1-10$.

Davis, R.B., C.F. Herreid II, and H.L. Short. 1962. Mexican free-tailed bats in Texas. Ecological Monographs 32:311-346.

Cross, S.P. 1965. The roosting habits of Pipistrellus hesperus. Journal of Mammalogy 46:270-279.

Drost, C. 2003. Scorpion Ranch House bat assessment. Report to National Park Service, Channel Islands National Park. 8 pp.

Easterla, D.A. 1973. Ecology of the 18 species of Chiroptera at Big Bend National Park, Texas. Part I. Northwest Missouri State University Studies 34: $1-53$.

Fellers, G.M., and E.D. Pierson. 2002. Habitat use and foraging behavior of Townsend's big-eared bat (Corynorhinus townsendii) in coastal California. Journal of Mammalogy 83:167-177.

FindLEY, J.S., AND C. JonEs. 1965. Comments on spotted bats. Journal of Mammalogy 46:679-680.

Genter, D.L. 1986. Wintering bats of the upper Snake River plain: occurrence in lava-tube caves. Great Basin Naturalist 46:241-244.

Gillam, E.H., G.F. McCracken, J.K. Westbrook, Y.-F. Lee, M.L. Jensen, and B.B. Balsley. 2009. Bats aloft: variability in echolocation call structure at high altitudes. Behavioral Ecology and Sociobiology 64:69-79.

GraHam, R.E. 1966. Observations on the roosting habits of the big-eared bat, Plecotus townsendii, in California limestone caves. Cave Notes 8:17-22.

Griffin, D.R. 1944. How bats guide their flight by supersonic echoes. American Journal of Physics 12: $342-345$. 
GRIFFIN, D.R. 1958. Listening in the dark: the acoustic orientation of bats and men. Yale University Press, New Haven, CT.

Grinnell, H.W. 1918. A synopsis of the bats of California. University of California Publications in Zoology $17: 223-404$.

Grinnell, J. 1910. A second record of the spotted bat (Euderma maculatum) for California. University of California Publications in Zoology 5:317-320.

HaLl, E.R. 1981. The mammals of North America. Volume 2. John Wiley \& Sons, Inc., New York, NY.

HaYwaRD, B.J., AND S.P. CROss. 1979. The natural history of Pipistrellus hesperus (Chiroptera: Vespertilionidae). Office of Research, Western New Mexico University, Silver City, New Mexico 3:1-36.

Hermanson, J.W., and J. O’Shea. 1983. Antrozous pallidus. Mammalian Species 213:1-8.

HolLOWAY, G.L., AND R.M.R. BARCLAY. 2001. Myotis ciliolabrum. Mammalian Species 670:1-5.

Howell, A.B. 1920. Contribution to the life history of the California mastiff bat. Journal of Mammalogy $1: 111-117$

Hulgard, K., C.F. Moss, L. Jakobsen, and A. SurlykKe. 2016. Big brown bats (Eptesicus fuscus) emit intense search calls and fly in stereotyped flight paths as they forage in the wild. Journal of Experimental Biology 219:334-340.

Jakobsen, L., S. Brinklov, and A. Surlykke. 2013. Intensity and directionality of bat echolocation signals. Frontiers in Physiology 4:1-9.

Johnston, D.S., and M.B. Fenton. 2001. Individual and population-level variability in diets of pallid bats (Antrozous pallidus). Journal of Mammalogy 82: 362-373.

KellogG, L. 1916. Report upon mammals and birds found in portions of Trinity, Siskiyou and Shasta Counties, California. University of California Publications in Zoology 12:335-398.

KRUTZSCH, P.H. 1943. Zonal distribution of the California mastiff bat. Journal of Mammalogy 24:269.

Krutzsch, P.H. 1944. Notes on the little known pocketed bat. Journal of Mammalogy 25:201.

KrutZSCH, P.H. 1948. Ecological study of the bats of San Diego County, California. Master's thesis, University of California, Berkeley, CA. $184 \mathrm{pp}$

Krutzsch, P.H. 1955. Observations on the California mastiff bat. Journal of Mammalogy 36:407-414.

Kumirai, A., AND J.K. Jones JR. 1990. Nyctinomops femorosaccus. Mammalian Species 349:1-5.

KunZ, T.H. 1982. Lasionycteris noctivagans. Mammalian Species 172:1-5.

KunZ, T.H., AND A. KurTa. 1988. Capture methods and holding devices. Pages 1-30 in T.H. Kunz, editor, Ecological and behavioral methods for the study of bats. Smithsonian Institution Press, Washington, DC.

Kurta, A., AND R.H. BAKER. 1990. Eptesicus fuscus. Mammalian Species 356:1-10.

Kurta, A., AND G.C. LeHr. 1995. Lasiurus ega. Mammalian Species 515:1-7.

LEITNER, P. 1966. Body temperature, oxygen consumption, heart rate and shivering in the California mastiff bat, Eumops perotis. Comparative Biochemistry and Physiology 19:431-433.

Lemen, C., P.W. Freeman, J.A. White, and B.R. AnderSEN. 2015. The problem of low agreement among automated identification programs for acoustical surveys of bats. Western North American Naturalist $75: 218-225$
Lethaby, N., W. Fritz, P.W. Collins, and P. Gaede. 2012. Fall bird migration on Santa Barbara Island, California. Western Birds 43:118-150.

Manning, R.W., and J.K. Jones Jr. 1989. Myotis evotis. Mammalian Species 329:1-5.

McCracken, G.F., E.H. Gillam, J.K. Westbrook, Y.-F. Lee, M.L. Jensen, and B.B. Balsley. 2008. Brazilian free-tailed bats (Tadarida brasiliensis: Molossidae, Chiroptera) at high altitude: links to migratory insect populations. Integrative and Comparative Biology 48:107-118.

McCracken, G.F., J.P. Hayes, J. Cevallos, S.Z. Guffey, AND F.C. Romero. 1997. Observations on the distribution, ecology, and behavior of bats on the Galapagos Islands. Journal of Zoology (London) 243:757-770.

MEARns, E.A. 1898. A study of the vertebrate fauna of the Hudson Highlands, with observations on the Mollusca, Crustacea, Lepidoptera, and the flora of the region. Bulletin of the American Museum of Natural History 10:303-352.

Miller, G.S., JR. 1897. Migration of bats on Cape Cod, Massachusetts. Science 118:541-543.

Milner, J., C. Jones, And J.K. Jones Jr. 1990. Nyctinomops macrotis. Mammalian Species 351:1-4.

Morales, J.C., and J.W. BickHam. 1995. Molecular systematics of the genus Lasiurus (Chiroptera: Vespertilionidae) based on restriction site maps of the ribosomal mitochondrial genes. Journal of Mammalogy 76 : 730-749.

O'Farrell, M.J., and W.G. Bradley. 1970. Activity patterns of bats over a desert spring. Journal of Mammalogy 51:18-26.

O’Farrell, M.J., and W.L. Gannon. 1999. A comparison of acoustic versus capture techniques for the inventory of bats. Journal of Mammalogy 80:24-30.

O'Farrell, M.J., and W.E. Hass. 2002. Autumn report bat survey of San Clemente Island, Los Angeles County, California. Prepared for Natural Resources Office, Environmental Department, Navy Region Southwest. 34 pp.

O'Farrell, M.J., B.W. Miller, and W.L. Gannon. 1999. Qualitative identification of free-flying bats using the Anabat detector. Journal of Mammalogy 80:11-23.

O'Farrell, M.J., and E.H. Studier. 1980. Myotis thysanodes. Mammalian Species 137:1-5.

O’Farkell, M.J., J.A. Williams, and B. Lund. 2004. Western yellow bat (Lasiurus xanthinus) in southern Nevada. Southwestern Naturalist 49:514-518.

OвRist, M.K. 1995. Flexible bat echolocation: the influence of individual, habitat and conspecifics on sonar signal design. Behavioral Ecology and Sociobiology $36: 207-219$.

Ommundsen, P., C. Lausen, and L. Matthias. 2017. First acoustic records of the Brazilian free-tailed bat (Tadarida brasiliensis) in British Columbia. Northwestern Naturalist 98:132-136.

OrR, R.T. 1954. Natural history of the pallid bat, Antrozous pallidus (LeConte). Proceedings of the California Academy of Sciences 28:165-246.

Pearson, O.P., M.R. Koford, and A.K. Pearson. 1952. Reproduction of the lump-nosed bat (Corynorhinus rafinesquei) in California. Journal of Mammalogy 33:273-320.

Perkins, J.M., and C.E. Levesque. 1987. Distribution, status and habitat affinities of Townsend's big-eared bat Plecotus townsendii in Oregon. Technical Report \#86-6-01, Oregon Department of Fish and Wildlife, Nongame Wildlife Program. $50 \mathrm{pp}$. 
Perkins, J.M., J.R. Peterson, And A.J. Perkins. 1994. Roost selection in a Pleistocene relict-Plecotus townsendii [abstract]. Bat Research News 35:110.

Pierce, G.W., AND D.R. GRIFFIn. 1938. Experimental determination of supersonic notes emitted by bats. Journal of Mammalogy 19:454-455.

Pierson, E.D., and W.E. Rainey. 1996a. The distribution, status and management of Townsend's big-eared bat (Corynorhinus townsendii) in California. California Department of Fish and Wildlife, Bird and Mammal Conservation Program Report 96-7. 49 pp.

Pierson, E.D., And W.E. Rainey. 1996b. Distribution, habitat associations, status, and survey methodologies for three molossid bat species (Eumops perotis, Nyctinomops femorosaccus, Nyctinomops macrotis) and the vespertilionid (Euderma maculatum). California Department of Fish and Wildlife, Bird and Mammal Conservation Program Report 96-8. 46 pp.

Pierson, E.D., and W.E. Rainey. 1998. Distribution of the spotted bat, Euderma maculatum, in California. Journal of Mammalogy 79:1296-1305.

Pierson, E.D., W.E. Rainey, and C. Corben. 2006. Distribution and status of western red bats (Lasiurus blossevillii) in California. California Department of Fish and Wildlife, Habitat Conservation Planning Branch, Species Conservation and Recovery Program Report 2006-04. Sacramento, CA. 45 pp.

Pierson, E.D., W.E. Rainey, and D. Wyatt. 2011. Roosting and foraging habitat for the western red bat (Lasiurus blossevillii) in the Sacramento River valley of California. Report to the U.S. Fish and Wildlife Service, Red Bluff, CA. 57 pp.

Poerink, B.J., S. Lagerveld, and H. Verdaat. 2013. Pilot study. Bat activity in the Dutch offshore wind farms Owex and Pawp. The Fieldwork Company, Groningen, Netherlands. 19 pp.

Rainey, W.E., AND P.E. Brown. 2015. Bat survey Naval Base Ventura County, Point Mugu and San Nicolas Island, California. Tetra Tech Contract Number N62470-08-D-1008. 47 pp.

Rainey, W.E., AND P.E. BRown. 2017. 2015-2016 Bat survey Naval Base Ventura County, Point Mugu and San Nicolas Island, California. Tetra Tech Contract Number N62470-13-D-8016. 35 pp.

Ratcliffe, J.M., and L. JakobSEn. 2018. Don't believe the mike: behavioural, directional, and environmental impacts on recorded bat echolocation call measures. Canadian Journal of Zoology 96:283-288.

REYNOLDS, R.P. 1981. Elevational record for Euderma maculatum (Chiroptera: Vespertilionidae). Southwestern Naturalist 26:91-92.

Rodhouse, T.J., K.T. VierLing, and K.M. Irvine. 2011. A practical sampling design for acoustic surveys of bats. Journal of Wildlife Management 75:1094-1102.

Ross, A. 1961. Notes on food habits of bats. Journal of Mammalogy 42:66-71.

Russell, A.L., C.A. Pinzari, M.J. Vonhof, K.J. Olival, AND F.J. BonaCCORSO. 2015. Two tickets to paradise: multiple dispersal events in the founding of hoary bat populations in Hawai'i. PLOS ONE 10(6): e0127912

Russo, D., L. Ancillotto, And G. Jones. 2017. Bats are still not birds in the digital era: echolocation call variation and why it matters for bat species identification. Canadian Journal of Zoology 96:63-78.

Rydell, J., L. Bach, P. Bach, L.G. Diaz, J. FurmanKiewicz, N. Hagner-Wahlsten, E.-M. Kyhero- einen, T. Lilley, M. Masing, M.M. Meyer, et al. 2014. Phenology of migratory bat activity across the Baltic Sea and the south-eastern North Sea. Acta Chiropterologica 16:139-147.

Shump, K.A., JR., AND A.U. Shump. 1982. Lasiurus borealis. Mammalian Species 186:1-6.

Siders, M.S., M.J. Rabe, T.K. Snow, and K. Yasuda. 1999. Long foraging distances in two uncommon bat species (Euderma maculatum and Eumops perotis) in northern Arizona. Pages 113-122 in C. van Riper III and M.A. Stuart, editors, Proceedings of the Fourth Biennial Conference of Research on the Colorado Plateau. U.S. Geological Survey, Flagstaff, AZ. Volume 4. Rep. Ser. USGS/FRESC/COPL/1999/16.

Simmons, J.A., W.A. LaVender, B.A. Lavender, J.E. Chids, K. Hulebak, M.R. Rigden, J. Sherman, B. WoolMAN, AND M.J. O'FARRELL. 1978. Echolocation by free-tailed bats (Tadarida). Journal of Comparative Physiology 125:291-299.

SimPSON, M.R. 1993. Myotis californicus. Mammalian Species 428:1-4.

StageR, K.E. 1943. Notes on the roosting place of Pipistrellus hesperus. Journal of Mammalogy 24: 266-267.

Stihler, C.W., and J.S. HaLl. 1993. Endangered bat populations in West Virginia caves gated or fenced to reduce human disturbance. Bat Research News 34: 130.

TEnAZA, R.R. 1966. Migration of hoary bats on South Farallon Island, California. Journal of Mammalogy 47:533-535.

Tuttle, M.D., AND D.A.R. TaYlor. 1994. Bats and mines. Bat Conservation International, Austin, TX.

Van Deusen, H.M. 1961. Yellow bat collected over South Atlantic. Journal of Mammalogy 42:530-531.

Van Gelder, R.G., and D.B. Wingate. 1961. The taxonomy and status of bats in Bermuda. American Museum Novitates 2029:1-9.

Vaughan, T.A. 1959. Functional morphology of three bats: Eumops, Myotis and Macrotus. University of Kansas Publications 12:1-153.

Von Bloeker, J.C. 1967. The land mammals of the Southern California Islands. Pages 245-263 in R.N. Philbrick, editor, Proceedings of the Symposium on the Biology of the California Islands. Santa Barbara Botanic Garden, Santa Barbara, CA.

Warner, R.M., and N.J. CZaplewski. 1984. Myotis volans. Mammalian Species 224:1-4.

Watkins, L.C. 1977. Euderma maculatum. Mammalian Species 77:1-4.

Whitaker, J.O., JR., C. Maser, and L.E. Keller. 1977. Food habits of bats of western Oregon. Northwest Science 51:46-55.

WiLKInS, K.T. 1989. Tadarida brasiliensis. Mammalian Species 331:1-10.

Woodsworth, G.C., G.P. Bell, and M.B. Fenton. 1981. Observations of the echolocation, feeding behavior, and habitat use of Euderma maculatum (Chiroptera: Vespertilionidae) in southcentral British Columbia. Canadian Journal of Zoology 59:1099-1102.

Received 18 May 2017 Revised 16 April 2018 Accepted 2 May 2018

Published online 8 November 2018 